\title{
Pengaruh fortifikasi ekstrak kulit buah naga super merah (Hylocereus costaricensis) terhadap kandungan antioksidan tape singkong kuning (Manihot utilissima Pohl)
}

\author{
Effect of fortification of super red dragon fruit peels extract (Hylocereus costaricensis) on \\ antioxidant content of fermented yellow cassava (Manihot utilissima Pohl)
}

\author{
Ni’ matusyukriyah $^{1)^{*}}$, Muh. Aniar Hari Swasono ${ }^{1)}$ \\ ${ }^{1}$ Program Studi Ilmu Teknologi Pangan, Fakultas Pertanian, Universitas Yudharta Pasuruan \\ email : nimatussyukriyah8@gmail.com
}

\begin{abstract}
This study aims to determine the effect of increasing the percentage of super red dragon fruit peel and adding the percentage of yeast tape to antioxidant activity. The method used in the study of making cassava tape with antioxidant fortification using factorial randomized block design (RBD) which consists of 2 factors, the first factor consists of 3 levels and the second factor consists of 3. Of the two factors obtained 6 treatment combinations. Each treatment was repeated three times so that 18 treatment combinations were obtained. The tests included physicochemical tests (antioxidant activity, $\mathrm{pH}$, color intensity) and organoleptic tests (color, aroma, taste, and texture). Analysis of physicochemical test data using ANOVA. If significantly different, then proceed with the Tukey test and to find the best treatment according to physicochemical parameters using the Zelleny method. Organoleptic test data analysis uses the Friedman test and to find the best treatment according to organoleptic parameters using the Effectiveness Index method. The results of this study indicate that the combination treatment of the addition of super red dragon fruit peels by $30 \% \mathrm{w} / \mathrm{v}$ and the percentage of yeast tape $0,4 \% \mathrm{w} / \mathrm{w}$ are the best results according to the physicochemical test parameters with characteristics: DPPH\% Inhibition (83.115\%), pH (4.53), color intensity L (50.2), color intensity $a+(47.7)$, color intensity $b+$ (12.32). The best treatment of organoleptic test was obtained from the combination of the treatment of the percentage of the addition of super red dragon fruit peels by $30 \% \mathrm{w}$ $/ v$ and the percentage of yeast tape $0.4 \% \mathrm{w} / \mathrm{w}$ with the provision that the average value of the organoleptic test score was 3.97 (likes), aroma 3.77 (like), texture 2.77 (enough), taste 3.5 (like).
\end{abstract}

Keywords: super red dragon fruit peels, fermented yellow cassava, antioxidant

\begin{abstract}
ABSTRAK
Penelitian ini bertujuan untuk mengetahui pengaruh penambahan persentase kulit buah naga super merah dan penambahan persentase ragi tape terhadap aktivitas antioksidan. Metode yang dipergunakan dalam penelitian pembuatan tape singkong dengan fortifikasi antioksidan dengan menggunakan Rancangan Acak Kelompok (RAK) faktorial dimana terdiri dari 2 faktor, faktor pertama terdiri dari 3 level dan faktor kedua terdiri dari 3. Dari kedua faktor tersebut didapat 6 kombinasi perlakuan. Masing-masing perlakuan diulang sebanyak tiga kali, sehingga didapat 18 kombinasi perlakuan. Uji yang dilakukan meliputi uji fisikokimia (aktivitas antioksidan, $\mathrm{pH}$, Intensitas warna) dan uji organoleptik (warna, aroma, rasa dan tekstur). Analisa data uji fisikokimia menggunakan ANOVA. Jika berbeda nyata, maka dilanjutkan dengan uji Tukey dan untuk mencari perlakuan terbaik sesuai parameter fisikokimia menggunakan metode Zelleny. Analisa data uji organoleptik menggunakan uji Friedman dan untuk mencari
\end{abstract}


perlakuan terbaik sesuai parameter organoleptik menggunakan metode Indeks Efektifitas. Hasil penelitian ini menunjukkan bahwa kombinasi perlakuan persentase penambahan kulit buah naga super merah sebesar $30 \% \mathrm{~b} / \mathrm{v}$ dan persentase ragi tape $0,4 \% \mathrm{~b} / \mathrm{b}$ adalah merupakan hasil terbaik sesuai parameter uji fisikokimia dengan karakteristik: DPPH \% Inhibisi $(83,115 \%)$, pH $(4,53)$, Intensitas warna L $(50,2)$, Intensitas warna $a+(47,7)$, Intensitas warna $b+(12,32)$. Perlakuan terbaik uji organoleptik diperoleh dari kombinasi perlakuan persentase penambahan kulit buah naga super merah sebesar $30 \% \mathrm{~b} / \mathrm{v}$ dan persentase ragi tape $0,4 \% \mathrm{~b} / \mathrm{b}$ dengan ketentuan rata-rata nilai skor uji organoleptik warna 3,97 (suka), aroma 3,77 (suka), tekstur 2,77 (cukup), rasa 3,5 (suka).

Kata Kunci : kulit buah naga super merah, tape singkong kuning, antioksidan

\section{PENDAHULUAN}

Buah naga merupakan salah satu genus Hylocereus dan Selenicereus. Bagian buah naga yang banyak dimanfaatkan adalah daging buahnya. Sedangkan kulitnya yang mempunyai berat $30 \%-35 \%$ dari berat buah belum dimanfaatkan dan hanya dibuang sebagai sampah, padahal kulit buah naga yang berwarna merah menunjukkan adanya pewarna alami yang terkandung dalam kulit buah naga (Shofiati et al., 2014).

Kulit buah naga mengandung vitamin C, flavonoid, tanin, alkaloid, steroid, dan saponin (Noor, Yuvita, dan Zulfalina, 2016). Pada penelitian mengenai total kandungan fenolik dan total serat pangan (TSP), aktivitas antioksidan dan antiproliferatif buah naga merah serta jambu biji merah pada sel melanoma, dapat disimpulkan bahwa kedua buah tersebut merupakan sumber utama antioksidan dan agen antikanker. Bahkan TSP dalam daging buah naga merah besarnya sama dengan yang ada pada kulitnya. Makin tinggi nilai TSP, makin tinggi pula aktivitas antioksidan (Hattunisa, 2009). Aktivitas antioksidan pada kulit buah naga lebih besar dibandingkan aktivitas antioksidan pada daging buahnya, sehingga berpotensi untuk dikembangkan menjadi sumber antioksidan alami. Hal ini sesuai dengan penelitian yang dilakukan oleh Nurliyana et al. (2010) yang menyatakan bahwa di dalam $1 \mathrm{mg} / \mathrm{ml}$ kulit buah naga merah mampu menghambat 83,48 $\pm 1,02 \%$ radikal bebas, sedangkan pada daging buah naga hanya mampu menghambat radikal bebas sebesar $27,45 \pm 5,03 \%$.
Kulit buah naga dapat dimanfaatkan sebagai pewarna alami dalam pembuatan tape singkong kuning. Tape singkong kuning merupakan hasil fermentasi singkong oleh ragi yang mengandung kapang, khamir, bakteri asam laktat, dan bakteri amilolitik (Khasanah dan Wikandari, 2014). Populasi campuran dalam ragi tape tediri dari spesiesspesies genus Aspergilius, Saccharomyces, Candida, Hansenulla, dan bakteri Acetobacter. Genu tersebut hidup bersamasama secara sinergis. Aspergillus menyederhanakan tepung menjadi glukosa serta memproduksi enzim glukoamilase yang akan memecah pati dengan mengeluarkan unitunit glukosa, sedangkan Saccharomyces, Candida dan Hansenulla dapat menguraikan gula menjadi alkohol dan bermacam-macam zat organik lain sementara itu Acetobacter dapat merombak alkohol menjadi asam (Tarigan, 1988 dalam Hasanah et al., 2012). Fermentasi tape dapat meningkatkan kandungan Vitamin B1 (tiamin) hingga tiga kali lipat. Vitamin ini diperlukan oleh sistem saraf, sel otot, dan sistem pencernaan agar dapat berfungsi dengan baik. Karena mengandung berbagai macam bakteri "baik" yang aman dikonsumsi, tape dapat digolongkan sebagai sumber probiotik bagi tubuh dan dapat mencegah terjadinya anemia, karena mikroorganisme yang berperan dalam fermentasinya mampu menghasilkan vitamin B12 (Nuraida dan Owens, 2014).

Penelitian tentang pemanfaatan limbah kulit buah naga dari berbagai varietas (super red, merah dan putih) menunjukkan bahwa total fenol, total betacyanin, dan aktivitas penangkapan radikal DPPH tertinggi adalah 
varietas kulit buah naga super red (Shofiati, Andriani, dan Anam 2014). Oleh karena itu perlu dilakukan penelitian lanjutan tentang kajian pemanfaaatan limbah kulit buah naga super merah sebagai fortifikasi dalam pembuatan tape singkong kuning yang selain sebagai pengembangan produk, juga untuk meningkatkan kandungan gizi tape singkong kuning.

Permasalahan yang timbul adalah belum diketahuinya persentase penambahan kulit buah naga super merah dan penambahan ragi tape yang tepat sehingga dihasilkan tape singkong kuning dengan kualitas terbaik ditinjau dari aspek fisikokimia dan organoleptik tape singkong kuning dengan fortifikasi antioksidan.

\section{METODE PELAKSANAAN}

\section{Bahan}

Bahan-bahan yang diperlukan dalam penelitian dengan jumlah 18 kombinasi perlakuan, antara lain: air sumber (18000 $\mathrm{ml}$ ), kulit buah naga dari buah naga yang dibeli di pasar porong kabupaten Sidoarjo (4800 g), singkong yang diperoleh dari pasar porong kabupaten Sidoarjo (9000 g), ragi cap pisang $(54 \mathrm{~g})$. bahan yang digunakan untuk analisa adalah aquadest, DPPH (1,1diphenyl-2-picrylhydrazil).

\section{Alat}

Alat yang digunakan untuk penelitian, antara lain: timbangan analitik digunakan untuk menimbang ragi tape, timbangan dapur digunakan untuk menimbang singkong kuning dan kulit buah naga super merah, panci digunakan untuk proses pemanasan singkong kuning, baki digunakan untuk proses pendinginan, kompor gas sebgagai sumber panas dalam proses pemanasan singkong kuning, daun pisang digunakan untuk membungkus pada saat proses pemeraman/fermentasi, pisau digunakan untuk mengupas dan memotong singkong kuning serta buah naga super merah, blender (Philips HR2116) digunakan untuk menghancurkan kulit buah naga super merah, gelas ukur digunakan untuk menakar air, mortal martil digunakan untuk meng- haluskan ragi tape, saringan teh digunakan untuk menaburkan bubuk ragi tape, besek digunakan untuk wadah proses fermentasi, talenan digunakan untuk alas pada saat pemotongan, stopwatch digunakan untuk menghitung waktu pemanasan. Alat yang digunakan dalam analisa fisikokimia adalah beaker glass, gelas ukur, sentrifuge, spektrofotometer, $\mathrm{pH}$ meter SI Analytics Lab 875, Color Reader CR-10

Alat yang digunakan untuk uji organoleptik tape singkong terfortifikasi antioksidan terdiri dari wadah besek tape dan sendok.

\section{Rancangan penelitian}

Metode yang dipergunakan dalam penelitian ini adalah dengan Rancangan Acak Kelompok (RAK) faktorial dimana terdiri dari 2 faktor, faktor pertama terdiri dari 2 perlakuan dan faktor kedua terdiri dari 3 perlakuan.

- Faktor pertama yaitu: persentase kulit buah naga super merah $(\mathrm{N})$ yang terdiri dari :

N0 : $0 \%$ b/v (0 gr kulit $+1000 \mathrm{ml}$ air $)$

$\mathrm{N} 1: 30 \% \mathrm{~b} / \mathrm{v}(300$ gr kulit $+1000 \mathrm{ml}$ air $)$

$\mathrm{N} 2: 50 \% \mathrm{~b} / \mathrm{v}(500$ gr kulit $+1000 \mathrm{ml}$ air $)$

- Faktor kedua yaitu: persentase ragi tape (R) yang terdiri dari :

$\mathrm{R} 1: 0.4 \% \mathrm{~b} / \mathrm{b}$ ( $2 \mathrm{gr}+500 \mathrm{gr}$ singkong kuning) $\mathrm{R} 2: 0.8 \% \mathrm{~b} / \mathrm{b}$ (4 gr +500 gr singkong kuning)

Dari kedua faktor tersebut didapat 6 kombinasi perlakuan. Masing-masing perlakuan diulang sebanyak tiga kali, sehingga didapat 18 kombinasi perlakuan.

\section{Metode pengumpulan data}

Analisa fisikokimia meliputi uji aktivitas antioksidan, $\mathrm{pH}$ dan intensitas warna. Uji aktivitas antioksidan pada penelitian ini menggunakan metode uji DPPH (1,1-diphenyl-2-picrylhydrazil), dengan prinsip DPPH memberikan serapan kuat pada radikal bebas. Ketika elektronnya menjadi berpasangan oleh keberadaan penangkap radikal bebas, maka absorbansinya menurun secara stokiometri sesuai jumlah elektron yang diambil. Keberadaan senyawa antioksidan dapat mengubah warna larutan DPPH dari ungu 
menjadi kuning. Pengukuran menggunakan spektrofotometer dengan panjang gelombang $517 \mathrm{~nm}$ (Wisesa et al., 2014) . Setelah itu dilakukan pengujian dengan mereaksikan dan dibiarkan pada suhu ruang selama 30 menit bertujuan untuk mencapai reaksi yang terjadi sempurna. Setelah 30 menit dilakukan pengukuran dengan spektrofotometer cahaya tampak. Hasil tersebut digunakan untuk penentuan nilai persen inhibisi atau persen perendaman senyawa antioksidan (sampel) terhadap DPPH (Hidayah, 2013). Uji derajat keasaman $(\mathrm{pH})$ dalam penelitian ini menggunakan alat $\mathrm{pH}$ meter SI Analytics Lab 875. Pengukuran $\mathrm{pH}$ dilakukan dengan mengacu pada metode SNI 06-6989.11-2004 yaitu $\mathrm{pH}$ sampel diukur menggunakan $\mathrm{pH}$ meter yang dikalibrasi terlebih dahulu. Elektroda $\mathrm{pH}$ meter kemudian dikeringkan menggunakan kertas tisu dan dibilas dengan akuades. Setelah itu $\mathrm{pH}$ sampel diukur dengan cara elektroda $\mathrm{pH}$ meter dimasukkan ke dalam gelas beker yang berisi sampel hingga skala atau angka di $\mathrm{pH}$ meter menunjukkan pembacaan yang tetap, kemudian hasilnya dicatat. Untuk pengukuran intensitas warna dalam penelitian ini menggunakan alat colour reader : $\mathrm{L}, \mathrm{a}+, \mathrm{b}+$. Analisa organoleptik dilakukan oleh 30 orang panelis tidak terlatih. Parameter yang digunakan untuk analisa organoleptik hedonic scale yaitu warna, aroma, tekstur dan rasa (Soekarto, 1985).

Metode yang digunakan untuk pengumpulan data analisa organoleptik meliputi warna, aroma, tekstur dan rasa dengan menggunakan uji skor (hedonic) pada 30 orang panelis tidak terlatih yang terdiri dari 15 orang laki-laki dan 15 orang perempuan dari golongan umur 7-50 tahun. Skala hedonic dalam uji organoleptik tape singkong kuning terfortifikasi antioksidan kulit buah naga super merah disajikan dalam bentuk angka dengan nilai 1 (Sangat tidak suka) sampai 5 (sangat suka).

\section{Metode analisa data}

Dalam penelitian ini analisa data fisikokimia dilakukan dengan menggunakan aplikasi Mini Tab untuk mencari data
Analysis of Variance (ANOVA) dan untuk menentukan notasi menggunakan Tukey Method. Untuk analisa data dari hasil uji organoleptik dihitung menggunakan uji Friedman, dan untuk mencari perlakuan terbaik sesuai uji fisikokimia dihitung menggunakan metode Zelleny, kemudian untuk mencari perlakuan terbaik uji organoleptik menggunakan metode Indeks Efektifitas De Garmo (1984) yang dimodifikasi Susrini (2003).

\section{HASIL DAN PEMBAHASAN}

\section{Analisa aktivitas antioksidan}

Pengujian aktivitas antioksidan dalam penelitian ini menggunakan metode DPPH (2,2-difenil-1-pikrilhidrazil) (Huang, 2005). Hasil perhitungan ANOVA yang dilanjut dengan uji Tukey terhadap aktivitas antioksidan tape singkong terfortifikasi kulit buah naga menunjukkan bahwa ada pengaruh yang sangat nyata antara kombinasi perlakuan persentase penambahan kulit buah naga super merah dengan persentase penambahan ragi tape. Tabel hasil uji Tukey disajikan pada Tabel 1 .

Tabel 1. Aktivitas antioksidan

\begin{tabular}{lc}
\hline \multicolumn{1}{c}{ Kombinasi Perlakuan } & $\begin{array}{c}\text { Mean } \\
\text { Antioksidan }\end{array}$ \\
\hline N1 R2 (Kulit buah naga 30\% ragi 0,8\%) & $84.01 \mathrm{a}$ \\
N1 R1 (Kulit buah naga 30\% ragi 0,4\%) & $83.12 \mathrm{ab}$ \\
N0 R2 (Kulit buah naga 0\% ragi 0,8\%) & $82.28 \mathrm{bc}$ \\
N0 R1 (Kulit buah naga 0\% ragi 0,4\%) & $82.04 \mathrm{c}$ \\
N2 R1 (Kulit buah naga 50\% ragi 0,4\%) & $78.10 \mathrm{~d}$ \\
N2 R2 9Kulit buah naga 50\% ragi 0,8\%) & $69.63 \mathrm{e}$ \\
\hline
\end{tabular}

Rerata hasil uji aktivitas antioksidan berkisar antara 69,63-84,01 yang dapat dilihat pada gambar 1 .

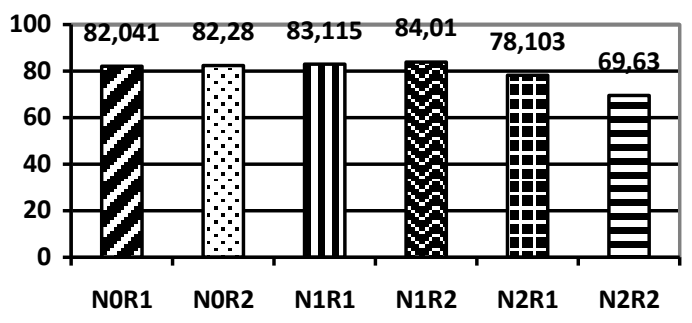

Gambar1. Histogram rata-rata kadar aktivitas antioksidan 
Pada Gambar 1 menunjukkan bahwa rata-rata kadar aktivitas antioksidan pada produk tape singkong terfortifikasi antioksidan kulit buah naga super merah dengan perbedaan perbandingan konsentrasi kulit buah naga super merah dan konsentrasi ragi berkisar antara 69,63\% - 84,01\%. Kadar aktivitas antioksidan tertinggi diperoleh pada kombinasi perlakuan persentase kulit buah naga super merah $30 \%$ dengan konsentrasi ragi $0,8 \%$ yaitu $84,01 \%$. Hal ini menunjukan bahwa perbandingan konsentrasi kulit buah naga dengan air pada saat proses ekstraksi yang optimal yakni perlakuan penambahan kulit buah naga super merah $30 \%$ dan akan menurun pada perlakuan penambahan kulit buah naga super merah $50 \%$.

Hasil rata-rata kadar aktivitas antioksidan tape singkong sample kontrol N0 (0\%) menyatakan bahwa sample tersebut mempunyai kadar aktivitas antioksidan yang sedang, yakni berkisar antara 82,04\%$82,28 \%$ karena singkong memiliki kandungan flavonoid yaitu $\beta$-karoten 10 $\mu \mathrm{g} / 100$ gram (Nayakrishi, 2007). $\beta$-karoten termasuk kelompok karotenoid yang merupakan pigmen warna kuning, merah dan oranye pada tumbuhan. Karotenoid dapat berfungsi sebagai prekursor vitamin A dan antioksidan (Wahyuni dan Widjanarko, 2015). Karotenoid juga merupakan scavenger yang efisien untuk radikal bebas sehingga dapat berfungsi sebagai antioksidan (Henrikson 2009 dalam Wahyuni dan Widjanarko 2015).

Sedangkan hasil rata-rata aktivitas antioksidan tape singkong terfortifikasi menunjukkan bahwa pada perlakuan N1 $(30 \%)$ memiliki hasil rata-rata aktivitas antioksidan yang lebih tinggi daripada perlakuan N2 (50\%). Proses ekstraksi kulit buah naga super merah dalam penelitian ini menggunakan air, sehingga selain betasianin yang memiliki kelarutan tinggi dalam air (Khuluq et al., 2007), ada kandungan antioksidan lain dalam ekstrak kulit buah naga super merah yang lebih mendominasi yakni asam galat. Sama halnya dengan betasianin, kandungan antioksidan yang berupa senyawa galat ini kurang larut dalam lemak dan cukup larut dalam air (Santoso, 2016).

Menurut penelitian Wu et al. (2006), hasil kandungan antioksidan kulit buah naga merah kering dapat dilihat pada Tabel 2 .

Tabel 2. Kandungan antioksidan kulit buah naga merah kering

\begin{tabular}{lc}
\hline Kandungan & $\begin{array}{c}\text { Kulit } \\
\text { kering /100g }\end{array}$ \\
\hline Asam galat & $39.7 \pm 5.39$ \\
Flanoid & $8.33 \pm 0.11$ \\
Betasianin & $13.8 \pm 0.85$ \\
Aktivitas antioksidan berdasarkan & $118 \pm 4.12$ \\
DPPH method at EC50 & $\mu$ mol \\
Pendekatan ABTS untuk Vit. C & $175 \pm 4.12$ \\
& $\mu \mathrm{mol}$ \\
\hline
\end{tabular}

Sumber: Wu et al. (2006)

Senyawa fenolik yang sangat aktif sebagai antioksidan alam dan paling banyak ditemukan dalam tanaman diantaranya adalah asam galat (Moon Shibamoto 2009). Santoso (2016) mengemukakan bahwa stabilitas senyawa galat terhadap panas meningkat dengan meningkatnya berat molekul. Ada tiga senyawa galat menurut Santoso (2016) yakni propil galat, dodesil galat dan oktil galat, akan tetapi dodesil dan oktil galat lebih larut dalam lemak/minyak daripada propil galat. Sehingga bisa diidentifikasikan bahwa senyawa galat yang larut pada saat proses ekstraksi yakni dari jenis propil galat. Sims and Fioriti (1980) dalam bukunya CRC Handbook of Food Additivies dalam Santoso (2016) menyebutkan bahwa titik didih propil galat akan terdekomposisi di atas $148^{\circ} \mathrm{C}$.

Pada saat proses pemanasan ekstraksi kulit buah naga menggunakan air yang persentase air nya lebih tinggi daripada kulit buah naga yakni perlakuan N1 (30\%), maka kandungan air didalamnya akan lebih dulu mendidih karena titik didih air lebih kecil dari pada titik didih propil galat dan akhirnya sebelum senyawa propil galat terdekomposisi, air tersebut lebih dulu bereaksi dengan panas yakni akan mengalami penguapan, sedangkan yang persentase air nya sama dengan kulit buah naga yakni perlakuan $\mathrm{N} 2(50 \%)$ dapat diidentifikasikan bahwa kandungan air ekstrak tersebut telah dipenuhi oleh senyawa propil galat sehingga 
akan lebih mudah terdekomposisi.

Perbandingan nilai aktivitas antioksidan pada penambahan ragi yakni semakin menurunnya derajat keasaman yang diciptakan oleh ragi maka akan mengakibatkan nilai aktivitas antioksidan menurun. Sesuai dengan pendapat Cai et al., (1998) dalam Faridah (2016) bahwa pigmen betasianin memiliki stabilitas yang baik pada keadaan asam dengan rentang $\mathrm{pH}$ 5- 7 dan akan mengalami kerusakan pada $\mathrm{pH}$ dibawah atau diatasnya.

\section{Analisa pH}

Hasil perhitungan ANOVA yang dilanjut dengan uji Tukey menunjukkan bahwa tape singkong terfortifikasi kulit buah naga super merah ada pengaruh nyata antara kombinasi perlakuan terhadap $\mathrm{pH}$. Tabel hasil uji Tukey disajikan pada Tabel 3.

Tabel 3. Analisa pH

\begin{tabular}{lc}
\hline \multicolumn{1}{c}{ Kombinasi Perlakuan } & $\begin{array}{c}\text { Mean } \\
\text { pH }\end{array}$ \\
\hline N0 R1 (Kulit buah naga 0\% ragi 0,4\%) & $5.17 \mathrm{a}$ \\
N0 R2 (Kulit buah naga 0\% ragi 0,8\%) & $4.73 \mathrm{ab}$ \\
N1 R2 (Kulit buah naga 30\% ragi 0,8\%) & $4.60 \mathrm{~b}$ \\
N2 R1 (Kulit buah naga 50\% ragi 0,4\%) & $4.57 \mathrm{~b}$ \\
N1 R1 (Kulit buah naga 30\% ragi 0,4\%) & $4.53 \mathrm{~b}$ \\
N2 R2 (Kulit buah naga 50\% ragi 0,8\%) & $4.43 \mathrm{~b}$ \\
\hline
\end{tabular}

Hasil yang berkisar antara 4,43-5,16. Histogram rata-rata uji $\mathrm{pH}$ tape singkong terfortifikasi antioksidan kulit buah naga super merah disajikan pada Gambar 2.

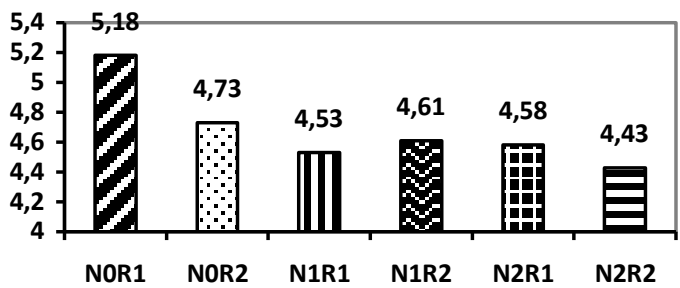

Gambar 2. Histogram rata-rata $\mathrm{pH}$.

Dari hasil rata-rata uji $\mathrm{pH}$ menunjukkan bahwa penambahan konsentrasi kulit buah naga menyebabkan penurunan $\mathrm{pH}$, karena pada kulit buah naga super merah megandung asam, sesuai dengan hasil penelitian Wahyuni (2011) kadar pH tertinggi diperoleh pada persentase penambahan kulit buah naga super merah sebesar $20 \%$ dan persentase karaginan $1 \%$ yaitu 5,91 dan terendah pada perlakuan persentase penambahan kulit buah naga super merah sebesar $60 \%$ dan karaginan 3\% yaitu 5,8 .

Perbandingan nilai $\mathrm{pH}$ pada beberapa kombinasi perlakuan penambahan konsentrasi ragi. Yang pertama pada kombinasi perlakuan kontrol NOR1-NOR2 menyatakan bahwa semakin banyak konsentrasi ragi yang digunakan maka $\mathrm{pH}$ tape akan semakin asam. Dalam penelitian Aini., Suranto dan Setyaningsih., (2003) jenis karbohidrat pada kedelai merupakan golongan oligosakarida dan polisakarida yang susah dicerna oleh inokulum kefir, sehingga semakin banyak konsentrasi kedelai yang digunakan maka perubahan $\mathrm{pH}$ semakin kecil. Sama halnya dengan kedelai,

jenis karbohidrat pada singkong merupakan jenis pati dari golongan polisakarida (Apriyani dan Sedyadi, 2015) dan oligosakarida yang susah dicerna oleh inokulum ragi tape, maka semakin banyaknya konsentrasi ragi tape dapat mempengaruhi perubahan $\mathrm{pH}$ yang semakin asam.

Yang kedua hasil uji $\mathrm{pH}$ pada perlakuan $\mathrm{N} 1$ menyatakan bahwa semakin banyak ragi maka kadar $\mathrm{pH}$ akan semakin tinggi. Telah dijelaskan sebelumnya bahwa, antioksidan yang mendominasi dalam larutan ekstrak kulit buah naga yakni dari golongan senyawa asam galat. Sedangkan asam galat mempunyai sifat dapat bergabung dengan glukosa membentuk tanin terhidrolisis (Hagerman 2002 dalam Junaidi dan Anwar 2018). Maka dapat disimpulkan bahwa sebelum inokulum dari ragi tape mencerna kandungan karohidrat singkong, senyawa asam galat lebih dulu bergabung dengan glukosa membentuk tanin terhidrolisis, sehingga kandungan karbohidrat dalam singkong berkurang dan pada akhirnya inokulum ragi tape dengan konsentrasi yang tinggi mengalami kekurangan nutrisi untuk pertumbuhan yang kemudian pertumbuhan akan menurun dan akhirnya pertumbuhan berhenti sama sekali. Berhentinya pertumbuhan dapat disebabkan karena berkurangnya beberapa nutrien esensial 
dalam medium atau karena terjadinya akumulasi aututuksin dalam medium atau kombinasi dari keduanya (Ansori, 1989 dalam Hasanah et al., 2012).

Yang ketiga sama halnya dengan perlakuan N0, pada perlakuan N2 kadar $\mathrm{pH}$ mengalami penurunan atau semakin asam dengan adanya penambahan persentase ragi tape. Hal ini disebabkan pada perlakuan N2 kandungan senyawa galat sudah tidak stabil, pada sub bab sebelumnya telah dijelaskan bahwa pada saat proses pemanasan kandungan air ekstrak tersebut telah dipenuhi oleh senyawa propil galat sehingga akan lebih mudah terdekomposisi. Sehingga kandungan antioksidan kulit buah naga super merah tersebut tidak mempengaruhi aktivitas pertumbuhan inokulum dari ragi tape yang menyebabkan meningkatnya $\mathrm{pH}$ pada penambahan ragi.

\section{Kecerahan (L)}

Nilai rata-rata tingkat kecerahan (L) pada berbagai kombinasi perlakuan berkisar antara 46,10-60,95. Hasil perhitungan ANOVA yang dilanjut dengan uji Tukey menunjukkan bahwa ada pengaruh yang sangat nyata antara persentase kulit buah naga dengan persentase ragi. Tabel hasil uji Tukey disajikan pada Tabel 4.

Tabel 4. Kecerahan (L)

\begin{tabular}{lc}
\hline \multicolumn{1}{c}{ Kombinasi Perlakuan } & $\begin{array}{c}\text { Mean } \\
\text { L }\end{array}$ \\
\hline N0 R1 (Kulit buah naga 0\% ragi 0,4\%) & $60.95 \mathrm{a}$ \\
N0 R2 (Kulit buah naga 0\% ragi 0,8\%) & $56.90 \mathrm{~b}$ \\
N1 R2 (Kulit buah naga 30\% ragi 0,8\%) & $50.60 \mathrm{c}$ \\
N1 R1 (Kulit buah naga 30\% ragi 0,4\%) & 50.20d \\
N2 R1 (Kulit buah naga 50\% ragi 0,4\%) & $46.40 \mathrm{e}$ \\
N2 R2 (Kulit buah naga 50\% ragi 0,8\%) & $46.10 \mathrm{f}$ \\
\hline
\end{tabular}

Histogram hasil rata-rata dari uji intensitas warna tingkat kecerahan (L) terhadap tape singkong terfortifikasi antioksidan disajikan pada Gambar 3.

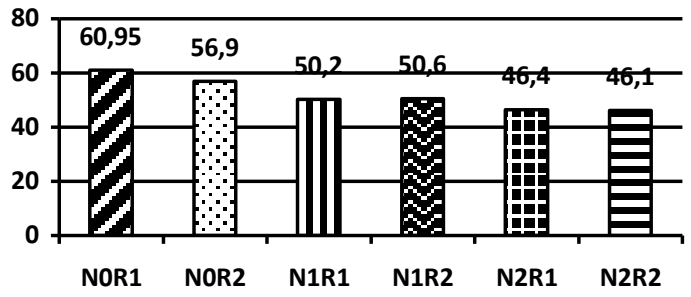

Gambar 3. Histogram rata-rata intensitas warna kecerahan $(\mathrm{L})$.

Karotenoid merupakan pigmen warna kuning, merah dan oranye pada tumbuhan. Semakin tinggi nilai L maka tingkat kecerahan pada tape semakin cerah. Dari hasil uji intensitas warna tingkat kecerahan (L) menyimpulkan bahwa setiap perlakuan yang semakin banyak konsentrasi penambahan ekstrak kulit buah naga super merah menghasilkan nilai intensitas warna kecerahan yang semakin rendah disebabkan adanya tambahan pigmen dari kulit buah naga. Kandungan pigmen yang tinggi mempengaruhi tingkat kecerahan (Khuluq et al., 2007)

Perbandingan nilai $\mathrm{L}$ pada penambahan ragi. Pada perlakuan yang memiliki hasil uji $\mathrm{pH}$ yang lebih rendah maka intensitas warna kecerahan semakin rendah. Karotenoid stabil pada $\mathrm{pH}$ netral, alkali namun tidak stabil pada kondisi asam, adanya udara atau oksigen, cahaya dan panas (Legowo, 2005). Sesuai dengan hasil penelitian Wahyuni dan Widjanarko (2015) yang menyatakan bahwa, pigmen karotenoid labu kuning cukup stabil terhadap larutan $\mathrm{pH}$ yang bersifat netral dan basa. Namun pada pH 3 dan 5 absorbansi cenderung turun yang menandakan bahwa warna pada karotenoid memudar. Karotenoid tidak stabil karena mudah teroksidasi oleh adanya oksigen dan peroksida. Selain itu, dapat mengalami isomerisasi bila terkena panas, cahaya dan asam. Isomerisasi dapat menyebabkan penurunan intensitas warna dan titik cair. Sesuai dengan hasil penelitian yang dilakukan Shofiati et al. (2014) penambahan kulit jeruk lemon pada konsentrasi yang berbeda dapat meningkatkan nilai kecerahannya (L). Hal ini dikarenakan kulit jeruk lemon mempunyai 
pigmen karotenoid. Sehingga karotenoid yang banyak mengalami isomerisasi akan menyebabkan intensitas warna kecerahan menurun.

\section{Kemerahan (a+)}

Nilai rata-rata tingkat kemerahan $(\mathrm{a}+)$ pada berbagai kombinasi perlakuan berkisar antara 1,60-21,25. Hasil perhitungan ANOVA yang dilanjut dengan uji Tukey menunjukkan bahwa ada pengaruh yang sangat nyata antara persentase kulit buah naga dengan persentase ragi. Tabel hasil uji Tukey disajikan pada Tabel 5.

Tabel 5. Kemerahan $(\mathrm{a}+)$

\begin{tabular}{lc}
\hline Kombinasi Perlakuan & $\begin{array}{c}\text { Mean } \\
\mathbf{a +}\end{array}$ \\
\hline N2 R1 (Kulit buah naga 50\% ragi 0,4\%) & $21.25 \mathrm{a}$ \\
N2 R2 (Kulit buah naga 50\% ragi 0,8\%) & $18.68 \mathrm{~b}$ \\
N1 R1 (Kulit buah naga 30\% ragi 0,4\%) & $15.90 \mathrm{c}$ \\
N1 R2 (Kulit buah naga 30\% ragi 0,8\%) & $15.40 \mathrm{~d}$ \\
N0 R2 (Kulit buah naga 0\% ragi 0,8\%) & $2.70 \mathrm{e}$ \\
N0 R1 (Kulit buah naga 0\% ragi 0,4\%) & $1.60 \mathrm{f}$ \\
\hline
\end{tabular}

Histogram hasil uji intensitas warna tingkat kemerahan terhadap tape singkong terfortifikasi antioksidan kulit buah naga super merah disajikan pada Gambar 4

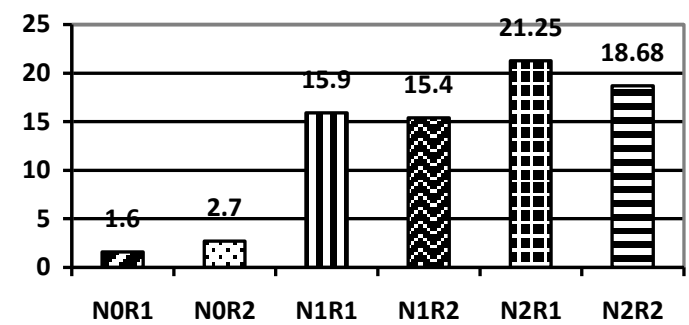

Gambar 4. Histogram rata-rata intensitas warna kemerahan $(a+)$

Gambar 4. menunjukkan bahwa tingkat intensitas warna kemerahan tertinggi diperoleh pada kombinasi perlakuan persentase kulit buah naga $50 \%$ b/v dan persentase ragi $0,4 \% \mathrm{~b} / \mathrm{b}$. Penambahan kulit buah naga pada tape memberikan peningkatan terhadap nilai a. semakin tinggi nilai a maka tingkat kemerahan pada tape semakin meningkat. kemerahan ekstrak kulit buah naga super merah sangat dipengaruhi oleh konsentrasi betasianin. dengan semakin meningkatnya kandungan betasianin akan membuat kemerahan warna tape tersebut semakin tinggi. Menurut Herbach, Stinzing, dan Carle (2006) menyatakan bahwa kenaikan dan penurunan intensitas warna merah ekstrak dipengaruhi oleh besar kecilnya kadar betasianin pada bahan.

Perbandingan nilai uji intensitas warna kemerahan (a+) antara perlakuan penambahan ragi. Peningkatan $\mathrm{pH}$ menunjukkan warna kemerahan memudar karena kation flavilium yang berwarna merah mengalami hidrasi menjadi karbinol tidak berwarna karbinol (Hidayah, 2013). Sehingga dapat disimpulkan bahwa, pada kandungan betasianin tinggi, intensitas warnanya semakin merah dan jika terjadi penurunan kandungan betasianin, intensitas merah juga menurun diiringi dengan meningkatnya nilai kecerahan (Shofiati et al., 2014). Hasil uji intensitas warna kemerahan menunjukkan perbedaan pada perlakuan N2 yang mana peningkatan penambahan ragi memberikan nilai a semakin turun. Hal ini sesuai dengan pendapat Cai et al. (1998) dalam Faridah (2016) bahwa pigmen betasianin memiliki stabilitas yang baik pada keadaan asam dengan rentang $\mathrm{pH}$ 5-7 dan akan mengalami kerusakan pada $\mathrm{pH}$ dibawah atau diatasnya.

\section{Kekuningan (b+)}

Nilai rata-rata tingkat kekuningan $(\mathrm{b}+)$ pada berbagai kombinasi perlakuan berkisar antara 7,91-28,18. Hasil perhitungan ANOVA yang dilanjut dengan uji Tukey menunjukkan bahwa ada pengaruh yang sangat nyata antara persentase kulit buah naga dengan persentase ragi. Tabel hasil uji Tukey disajikan pada Tabel 6 .

Tabel 6. Kekuningan (b+)

\begin{tabular}{lc}
\hline \multicolumn{1}{c}{ Kombinasi Perlakuan } & $\begin{array}{c}\text { Mean } \\
\text { b+ }\end{array}$ \\
\hline N0 R1 (Kulit buah naga 0\% ragi 0,4\%) & $28.18 \mathrm{a}$ \\
N0 R2 (Kulit buah naga 0\% ragi 0,8\%) & $25.25 \mathrm{~b}$ \\
N1 R2 (Kulit buah naga 30\% ragi 0,8\%) & $16.17 \mathrm{c}$ \\
N1 R1 (Kulit buah naga 30\% ragi 0,4\%) & $12.32 \mathrm{~d}$ \\
N2 R2 (Kulit buah naga 50\% ragi 0,8\%) & $9.63 \mathrm{e}$ \\
N2 R1 (Kulit buah naga 50\% ragi 0,4\%) & $7.91 \mathrm{f}$ \\
\hline
\end{tabular}

Histogram hasil uji intensitas warna tingkat kekunigan tape singkong terfortifikasi antioksidan kulit buah naga super merah disajikan pada Gambar 5. 


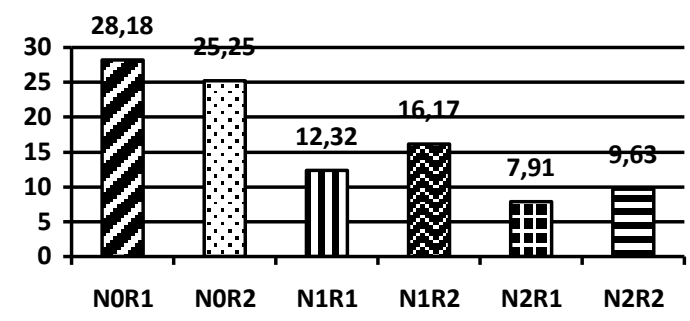

Gambar 5. Histogram rata-rata intensitas warna kekuningan $(b+)$.

Gambar 5. menunjukkan bahwa tingkat intensitas warna kekuningan tertinggi diperoleh pada kombinasi perlakuan kontrol N0 $(0 \%)$ dan persentase ragi $0,4 \% \mathrm{~b} / \mathrm{b}$. Penurunan serta peningkatan hasil uji intensitas warna kemerahan $(\mathrm{a}+)$ diiringi dengan peningkatan hasil uji intensitas warna kekuningan $(\mathrm{b}+)$ dengan demikian maka semakin banyak persentase penambahan kulit buah naga super merah akan menjadikan intensitas warna kekuningan semakin rendah. Sesuai dengan hasil penelitian Shofiati et al., (2014) mengemukakan bahwa nilai $b$ tertinggi terdapat pada teh celup kulit buah naga dengan penambahan kulit jeruk lemon $40 \%$, sedangkan nilai $\mathrm{b}$ terendah pada teh celup kulit buah naga tanpa penambahan kulit jeruk lemon. Penambahan kulit jeruk lemon pada konsentrasi yang berbeda dapat meningkatkan nilai kekuningan (b). Warna kekuningan pada teh celup kulit buah naga didominasi adanya pigmen karoten pada kulit jeruk lemon. Telah dijelaskan pada sub bab sebelumnya bahwa pada $\mathrm{pH} 3$ dan 5 absorbansi cenderung turun yang menandakan bahwa warna pada karotenoid memudar. Karotenoid tidak stabil karena mudah teroksidasi oleh adanya oksigen dan peroksida. Maka dapat disimpulkan bahwa persentase penambahan ragi akan menyebabkan nilai $\mathrm{pH}$ semakin asam kecuali pada perlakuan penambahan ragi $30 \% \mathrm{~b} / \mathrm{v}$, dan $\mathrm{pH}$ yang semakin asam akan mempengaruhi stabilitas karotenoid yang memberikan warna kekuningan pada produk tape singkong.

\section{Warna}

Berdasarkan hasil analisa organoleptik yang dilakukan terhadap 30 orang panelis menunjukkan bahwa nilai panelis terhadap warna tape singkong terfortifikasi kulit buah naga supe rmerah berkisar antara 1,9-4,53 yaitu antara tidak suka sampai sangat suka. Histogram hasil skoring tingkat kesukaan panelis terhadap warna tape singkong terfortifikasi kulit buah naga super merah disajikan pada Gambar 6.

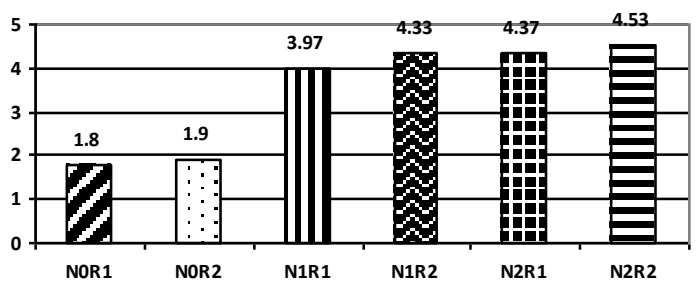

Gambar 6. Histogram rata-rata hasil skoring warna

Rata-rata nilai kesukaan panelis terhadap warna tape terfortifikasi kulit buah naga super merah mempunyai nilai terendah 1,9 dari kombinasi perlakuan NOR2 yakni tanpa penambahan kulit buah naga super merah $0 \%$ dan ragi $0,8 \%$, sedangkan nilai tertinggi 4,53 dari kombinasi perlakuan N2R2 yakni persentase kulit buah naga 50\% dan ragi $0,8 \%$. Menurut catatan panelis pada perlakuan N0R2 warna terlihat kuning pucat sedangkan pada perlakuan N2R2 terlihat merah muda. Hasil uji Friedman menunjukkan bahwa nilai $\mathrm{X}^{2}$ tabel lebih kecil dibandingkan nilai $\mathrm{X}$ Hitung, berarti ada beda nyata antara persentase penambahan kulit buah naga dengan persentase penambahan ragi.

Warna tape singkong dipengaruhi oleh komponen pembentuk warna dari kulit buah naga super merah dan singkong dan akan mengalami peningkatan serta penurunan pada setiap penambahan ragi. Warna yang dihasilkan tape singkong berasal dari kulit buah naga (pigmen betasianin) dan singkong (karotenoid). Betasianin merupakan pigmen yang memberikan warna merah sampai ungu (Harivaindaran et al., 2008). Dengan penambahan ragi akan mempengaruhi warna yang dihasilkan dari tape tanpa kulit buah 
naga dan dengan kulit buah naga. Semakin tinggi penambahan ragi akan menghasilkan perubahan $\mathrm{pH}$ yang pada akhirnya mempengaruhi stabilitas pigmen.

\section{Aroma}

Berdasarkan hasil analisa organoleptik yang dilakukan terhadap 30 orang panelis menunjukkan bahwa nilai panelis terhadap aroma tape singkong terfortifikasi kulit buah naga super merah berkisar antara 2,83-4 yaitu berkisar antara cukup sampai suka. Histogram rata-rata hasil skoring tingkat kesukaan panelis terhadap warna tape singkong terfortifikasi kulit buah naga super merah disajikan pada Gambar 7.

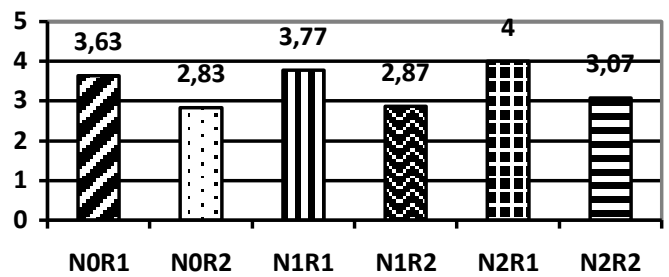

Gambar 7. Histogram rata-rata hasil skoring aroma

Rata-rata nilai kesukaan panelis terhadap warna tape terfortifikasi kulit buah naga super merah mempunyai nilai terendah 2,83 dari kombinasi perlakuan NOR2 yakni tanpa penambahan kulit buah naga super merah $0 \%$ dan ragi $0,8 \%$, sedangkan nilai tertinggi 4 dari kombinasi perlakuan N2R1 yakni persentase kulit buah naga $50 \%$ dan ragi $0,4 \%$. Menurut catatan panelis pada perlakuan NOR2 aroma tape cukup seperti aroma tape pada umumnya sedikit beralkohol sedangkan pada penambahan persentase kulit buah naga dapat memperbaiki aroma tape. Hasil uji Friedman menunjukkan bahwa nilai $\mathrm{X}^{2}$ Tabel lebih kecil dibandingkan nilai $\mathrm{X}$ Hitung, yang berarti ada perbedaan nyata antara persentase penambahan kulit buah naga dengan persentase penambahan ragi.

Semakin banyak dosis ragi yang diberikan maka semakin banyak alkohol yang terbentuk. Aroma khas pada tape disebabkan karena selama proses fermentasi perubahan tape, gula yang terbentuk akan diubah menjadi alkohol oleh aktivitas
Saccharomyces cerevisiae. Alkohol akan diubah menjadi asam organik oleh bakteri pedioccus melalui proses oksidasi alkohol, sebagian asam organik akan bereaksi dengan alcohol membentuk eter yang memberi cita rasa tape sehingga menghasilkan bau khas tape (Astawan 2004 dalam Puspitasari 2014).

\section{Tekstur}

Berdasarkan hasil analisa organoleptik yang dilakukan terhadap 30 orang panelis menunjukkan bahwa nilai panelis terhadap tekstur tape singkong terfortifikasi kulit buah naga super merah berkisar antara 2,17-3,47 yaitu berkisar antara tidak suka sampai cukup. Histogram rata-rata hasil skoring tingkat kesukaan panelis terhadap tekstur tape singkong terfortifikasi kulit buah naga super merah disajikan pada Gambar 8.

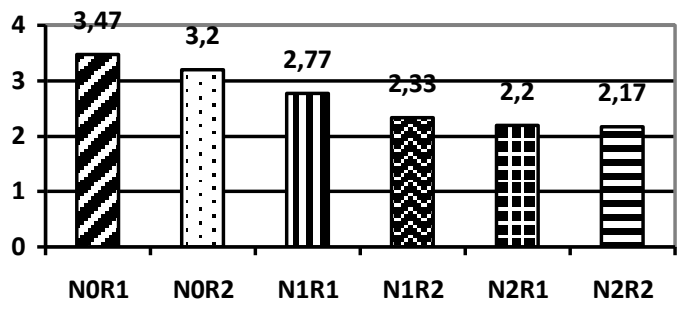

Gambar 8. Histogram rata-rata hasil skoring tekstur

Rata-rata nilai kesukaan panelis terhadap tekstur tape terfortifikasi kulit buah naga super merah mempunyai nilai terendah 2,17 dari kombinasi perlakuan N2R2 yakni penambahan kulit buah naga super merah $50 \%$ dan ragi $0,8 \%$, sedangkan nilai tertinggi 3,47 dari kombinasi perlakuan N0R1 yakni tanpa penambahan kulit buah naga 0\% dan ragi $0,4 \%$. Menurut catatan panelis pada perlakuan NOR1 tekstur tape lunak sedangkan pada penambahan persentase kulit buah naga mengakibatkan tekstur tape berair. Menurut Wanto dan Subagyo dalam Maimuna (2004) Khamir mempunyai kemampuan untuk memecah pangan karbohidrat menjadi alkohol dan karbondioksida. Proses ini diketahui sebagai fermentasi alkohol yaitu proses anaerob. Khamir mempunyai sekumpulan enzim yang diketahui sebagai zymase yang berperan 
pada fermentasi senyawa gula, seperti glukosa menjadi etanol dan karbondioksida. Reaksi yang terjadi dalam fermentasi alkohol sebagai berikut: $\mathrm{C}_{6} \mathrm{H}_{12} \mathrm{O}_{6} \longrightarrow 2 \mathrm{C}_{2} \mathrm{H}_{5} \mathrm{OH}+2$ $\mathrm{CO}_{2}$. Jika pemberian $\mathrm{O} 2$ berlebihan, sel khamir akan melakukan respirasi secara aerobik, dalam keadaan ini enzim khamir dapat memecah senyewa gula lebih sempurna, dan akan dihasilkan karbondioksida dan air.

Hasil uji Friedman menunjukkan bahwa nilai $\mathrm{X}^{2}$ Tabel lebih kecil dibandingkan nilai $X$ Hitung, berarti ada perbedaan nyata antara persentase penambahan kulit buah naga dengan persentase penambahan ragi.

\section{Rasa}

Berdasarkan hasil analisa organoleptik yang dilakukan terhadap 30 orang panelis menunjukkan bahwa nilai panelis terhadap rasa tape singkong terfortifikasi kulit buah naga super merah berkisar antara 3-3,5 yaitu berkisar antara cukup sampai suka. Histogram rata-rata hasil skoring tingkat kesukaan panelis terhadap rasa tape singkong terfortifikasi kulit buah naga super merah disajikan pada Gambar 9.

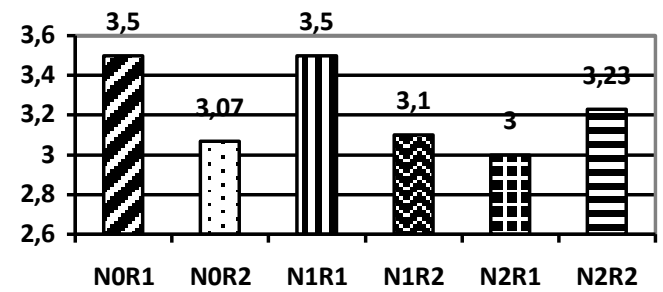

Gambar 9. Histogram rata-rata hasil skoring rasa

Rata-rata nilai kesukaan panelis terhadap rasa tape terfortifikasi kulit buah naga super merah mempunyai nilai terendah 3 dari kombinasi perlakuan N2R1 yakni penambahan kulit buah naga super merah $50 \%$ dan ragi $0,4 \%$, sedangkan nilai tertinggi 3,5 dari kombinasi perlakuan NOR1 (kulit buah naga super merah $0 \%$ dan ragi $0,4 \%$ ) dan N1R1 (kulit buah naga super merah $30 \%$ dan ragi $0,4 \%$ ). Menurut catatan panelis pada perlakuan N2R1 rasa tape cukup seperti rasa tape pada umumnya di pasaran sedangkan pada perlakuan NOR1 dan N1R1 memiliki rasa yang manis. Menurut Tarigan (1988) dalam Hasanah et al. (2012) ragi tape merupakan populasi campuran yang tediri dari spesies-spesies genus Aspergilius, Saccharomyces, Candida, Hansenulla, dan bakteri Acetobacter. Genus tersebut hidup bersama-sama secara sinergis. Aspergillus menyederhanakan tepung menjadi glukosa serta memproduksi enzim glukoamilase yang akan memecah pati dengan mengeluarkan unit-unit glukosa, sedangkan Saccharomyces, Candida dan Hansenulla dapat menguraikan gula menjadi alkohol dan bermacam-macam zat organik lain sementara itu Acetobacter dapat merombak alkohol menjadi asam. Beberapa jenis jamur juga terdapat dalam ragi tape, antara lain Chlamydoтисоr oryzae, Mucor sp, dan Rhizopus sp.

Hasil uji Friedman menunjukkan bahwa nilai $\mathrm{X}^{2}$ Tabel lebih besar dibandingkan nilai $\mathrm{X}$ Hitung, berarti tidak ada perbedaan nyata antara persentase penambahan kulit buah naga dengan persentase penambahan ragi, dalam artian antara persentase penambahan kulit buah naga dan persentase penambahan ragi samasama tidak mempengaruhi rasanya.

\section{Perlakuan terbaik uji fisikomia}

Penentuan perlakuan terbaik menggunakan metode Zelleny pada parameter uji fisikokimia yang meliputi uji DPPH \% Inhibisi, uji $\mathrm{pH}$, uji intensitas warna kecerahan (L), uji intensitas warna kemerahan $(a+)$, uji intensitas warna kekuningan $(\mathrm{b}+)$. Uji penentuan perlakuan terbaik dengan metode Zelleny. Indeks efektifitas fisikokimia disajikan pada tabel 7 .

Tabel 7. Indeks efektifitas fisikokimia

\begin{tabular}{ccc}
\hline Kombinasi Perlakuan & $\begin{array}{c}\text { Nilai L } \\
\text { maksimal }\end{array}$ \\
\hline N1 R1 (Kulit buah naga 30\% ragi) $0,4 \%$ & $0.189 *$ \\
N1 R2 (Kulit buah naga 30\% ragi) $0,8 \%$ & 0.230 \\
N2 R1 (Kulit buah naga 50\% ragi) $0,4 \%$ & 0.222 \\
N2 R2 (Kulit buah naga 50\% ragi) $0,8 \%$ & 0.226 \\
\hline
\end{tabular}

Keterangan: *: terbaik

Hasil perhitungan menunjukkan perlakuan terbaik terdapat pada perlakuan N1R1 (kulit buah naga 30\% dan ragi 0,4\%) dengan ketentuan fisikokimia DPPH \% 
Inhibisi $(83,115 \%), \mathrm{pH}(4,53)$, Intensitas warna L $(50,2)$, Intensitas warna a+ $(47,7)$, Intensitas warna $b+(12,32)$.

\section{Perlakuan terbaik uji organoleptik}

Penilaian keseluruhan parameter organoleptik meliputi warna, aroma, tekstur dan rasa tergabung dalam parameter perlakuan terbaik. Parameter secara keseluruhan ini menjadi sangat penting untuk mengetahui tingkat penerimaa konsumen terhadap suatu produk pangan. Uji penentuan perlakuan terbaik dengan metode indeks efektifitas De Garmo (1984) yang dimodifikasi Susrini (2003). Hasil perhitungan disajikan pada Tabel 6 .

Tabel 6. Indeks efektifitas organoleptik

\begin{tabular}{cc}
\hline Kombinasi Perlakuan & NP \\
\hline N1 R1 (Kulit buah naga 30\% ragi 0,4\%) & $0.71 *^{11}$ \\
N1 R2 (Kulit buah naga 30\% ragi 0,8\%) & 0.286 \\
N2 R1 (Kulit buah naga 50\% ragi 0,4\%) & $0.400 *^{3}$ \\
N2 R2 (Kulit buah naga 50\% ragi 0,8\%) & $0.413 *^{2}$ \\
\hline Ke
\end{tabular}

Keterangan: $* 1$ : terbaik $1, * 2$ : terbaik $2, * 3$ : terbaik 3

Tabel 6. menunjukkan bahwa perlakuan terbaik 1 terdapat pada perlakuan N1R1 Kulit buah naga 30\% dan ragi $0,4 \%$ dengan ketentuan rata-rata nilai skor uji organoleptik warna 3,97 (suka), aroma 3,77 (suka), tekstur 2,77 (cukup), rasa 3,5 (suka)

\section{KESIMPULAN}

Berdasarkan hasil penelitian dan pembahasan yang disesuaikan dengan tujuan penelitian, maka dapat disimpulkan sebagai berikut: 1) Aktivitas antioksidan akan meningkat pada penambahan ekstrak kulit buah naga super merah sebanyak $30 \%$ b/v. kemudian mengalami penurunan pada persentase penambahan kulit buah naga super merah sebanyak $50 \% \mathrm{~b} / \mathrm{v}$ pada pembuatan tape singkong. Faktor meningkat dan menurunnya aktivitas antioksidan dominan dipengaruhi oleh kandungan senyawa galat pada kulit buah naga super merah. 2) Kombinasi perlakuan terbaik uji organoleptik berdasarkan perhitungan indeks efektifitas De Garmo (1984) yang dimodifikasi oleh Susrini (2003) yakni kombinasi perlakuan N1R1 (kulit buah naga super merah $30 \% \mathrm{~b} / \mathrm{v}$ dan ragi $0,4 \% \mathrm{~b} / \mathrm{b}$ ), dengan karakteristik: DPPH \% Inhibisi (83,115\%), pH (4,53), Intensitas warna L $(50,2)$, Intensitas warna a+ $(47,7)$, Intensitas warna b+ (12,32). 3) Kombinasi perlakuan terbaik uji fisikokimia berdasarkan perhitungan indeks efektifitas Zelleny yakni kombinasi perlakuan N1R1 (kulit buah naga super merah $30 \% \mathrm{~b} / \mathrm{v}$ dan ragi $0,4 \% \mathrm{~b} / \mathrm{b}$ ), dengan ketentuan rata-rata nilai skor uji organoleptik warna 3,97 (suka), aroma 3,77 (suka), tekstur 2,77 (cukup), rasa 3,5 (suka).

\section{SARAN}

Berdasarkan penelitian yang telah dilakukan, saran yang dapat disampaikan yaitu: Perlu kajian lebih lanjut untuk mengidentifikasi jenis pigmen serta senyawa yang berperan sebagai antioksidan pada kulit buah naga super merah beserta karakteristik senyewa tersebut.

\section{DAFTAR PUSTAKA}

Aini, Y. N., Suranto \& R. Setyaningsih. (2003). Pembuatan kefir susu kedelai (Glycine max (L.) Merr) dengan variasi kadar susu skim dan inokulum. Jurnal Biosmart, 5(2), 8993.

Apriyani, M., \& Sedyadi, E. (2015). Sintesis dan karakterisasi plastik biodegradable dari pati onggok singkong dan ekstrak lidah buaya (Aloe vera) dengan plasticizer gliserol. Jurnal Sains Dasar, 4(2), $145-152$.

Harivaindaran, Rebecca, \& S.Chandran. (2008). Study of optimal temperature, ph and stability of dragon fruit (Hylocereus polyrhizus) peel for usa as potential natural colorant. Pakistan Journal of Biological Sciences, 11(18), 2259-2263.

Hasanah, H., Jannah, A., Fasya, A.G. (2012). Pengaruh lama fermentasi terhadap kadar alkohol tape singkong (Manihot utilissima Pohl). Alchemy Journal of Chemistry, 2(1), 86-79. 
Hattunisa, R. (2009). Kajian alternatif produk pangan fungsional yang dapat dikembangkan dari buah naga. Skripsi. IPB. Bogor.

Herbach, K. M., Stinzing, F. C., \& Carle, R. (2006). Structural and chromatic stability of purple pitaya (Hylocereus polyrhizus) [ Weber ] britton and rose) betacyanins as affected by the juice matrix and selected additives. Food Res. Int, 39, 667-677.

Hidayah, T. (2013). Uji stabilitas pigmen dan antioksidan hasil ekstraksi zat warna alami dari kulit buah naga (Hylocereus undatus). Skripsi tidak diterbitkan. Semarang. Universitas Negeri Semarang.

Junaidi, E., \& Anwar, Y.A.S. (2018). Aktivasi antibakteri dan antioksidan asam galat dari kulit buah lokal yang diproduksi dengan tanase. ALCHEMY Jurnal Penelitian Kimia, 14(1), 131142.

Khasanah, N., \& Wikandari, P. (2014). Pengaruh Lama Fermentasi dan Penambahan Bakteri Asam Laktat Lactobacillus plantarum terhadap Mutu Produk Tape Singkong. UNESA Journal of Chemistry, 3(1), 78-84.

Khuluq, A. D., Widjanarko, S. B. \& Murtini, E.S. (2007). Ekstraksi dan stabilitas betasianin daun darah (Alternanthera dentata) (kajian perbandingan pelarut air : etanol dan suhu ekstraksi). Jurnal Teknologi Pertanian, 8(3), 172-181

Legowo, A. (2005). Pengaruh Blanching terhadap Sifat Sensoris dan Kadar Provitamin Tepung Labu Kuning. Skripsi. Yogyakarta. Universitas Gadjah Mada.

Mitasari, A., (2012). Uji aktivitas ekstrak kloroform kulit buah naga merah (Hylocereus polyrhizus Britton \& Rose) menggunakan metode DPPH (1,1- Defenil-2-Pikril Hidrazil). Skripsi. Pontianak. Universitas Tanjungpura.

Muhiddin, N. H., Juli, N., Aryantha, I. N. P.
(2001). Peningkatan kandungan protein kulit umbi ubi kayu melalui proses fermentasi. JMS, 6(1),1-12.

Moelyaningrum, A.D. (2012). Hazard analysis critical point (HACCP) pada produk tape singkong untuk meningkatkan keamanan pangan tradisional indonesia. The Indonesian Journal of Health Science, 3(1), 4149.

Moon, J.K. \& Shibamoto, T. (2009). Antioxidant assays for plant and food components. Journal of Agricultural and Food Chemistry, 57(5), 16551666.

Nayakrishi. (2007). Community Food System Data. http://www.mcgill.com. 4 Juni 2019.

Noor, M. I., Yuvita, E., \& Zulfalina. (2016). Identifikasi kandungan ekstrak kulit buah naga merah menggunakan fourier transform infrared (FTIR) and phytochemistry. Journal of Aceh Physics Society (JacPS), 5(1), 14-16.

Nuraida, L., \& Owens, J.D. (2014). Sweet, sour, alcoholic solid substrate fungal fermentations. Indigenous Fermented Foods of Southeast Asia, 137(2).

Nurliyana, R., Zahir, I. S., Suleiman, K. M., Aisyah, M.R., Rahim, K. K. (2010). Antioxidant study of pulps and peels of dragon fruits: a comparative study. International Food Research Journal, 17(367).

Puspitasari, S.A. Uji kadar protein dan organoleptik tape singkong (Manihot utilissima) dengan penambahan sari buah pepaya (Carica papaya L.) dan dosis ragi yang berbeda. Skripsi. Universitas Muhammadiyah Surakarta. Surakarta.

Santoso, A.F \& Fibrianto, K. (2017). Pengaruh ekstrak kulit buah naga merah (Hylocereus polyrhizus) terhadap kualitas sosis ayam: tinjauan pustaka. Jurnal Pangan dan Agroindustri, 5(4), 92-96.

Shofiati, A., Andriani, M.AM. \& Anam, C. (2014). Kajian kapasitas antioksidan dan penerimaan sensoris teh celup 
kulit buah naga (pitaya fruit) dengan penambahan kulit jeruk lemon dan stevia. Jurnal Teknosains Pangan, 3(2), 5-13.

Wahyuni, D.T. \& Widjanarko, S.B. (2015). Pengaruh jenis pelarut dan lama ekstraksi terhadap ekstrak karotenoid labu kuning dengan metode gelombang ultrasonik. Jurnal Pangan dan Agroindustri, 3(2), 390-401.

Wahyuni, R. (2011). Pemanfaatan kulit buah naga super merah (Hylicereus costaricensis) sebagai sumber antioksidan dan pewarna alami pada pembuatan jelly . Teknologi Pangan, 2(1), 68-85.

Wisesa, T.B., \& Widjanarko, S.B., (2014). Penentuan nilai maksimum proses ekstraksi kulit buah naga merah (Hylocereus polyrhizus). Jurnal Pangan dan Agroindustri, 2(3), 8897.

Wu, L. C., Hsu, H. W., Chen, Y., Chiu, C. C., \& Ho, Y. I., (2006). Antioxidant and antiproliferative activities of red pitaya. Food Chemistry, 95(2), 319327. 